\title{
Informal Sectors and Unemployment in Nigeria: A Vector Error Correction Model (VECM) Approach
}

\author{
Messiah, Abaka John ${ }^{1}$, Olofin, Philip Olabode ${ }^{2 *}$ \\ ${ }^{I}$ Obafemi Awolowo University, Ile-Ife, Osun State, Nigeria \\ ${ }^{2}$ Department of Economics, Obafemi Awolowo University, Ile-Ife, Nigeria. \\ Corresponding Author: Messiah Abaka John
}

\begin{abstract}
Using the period between1981 and 2015, the study examined the impact of informal sector on unemployment in Nigeria. Unlike many other studies, various macro measures of informal sector were considered in the study. The study employed the Vector Error Correction Model (VECM). Findings from the study showed that informal sector proxied by the discrepancy between aggregate expenditure and aggregate income; currency ratio; discrepancy between labour force and formal employment; and human capital had a negative and statistically significant relationship with unemployment both in the short and the long run. Also, the results showed that in the short run, informal sectors and human capital had an automatic adjustment mechanism with the negative error-correction term which is statistically significant. The study concluded that informal sectors are capable of reducing unemployment in both the short and long-run in Nigeria.
\end{abstract}

Keywords: Informal Sector; Unemployment; Nigeria.

\section{Introduction}

Among the problems facing a highly populated country like Nigeria, with the population of about 177 million people, is high rate of unemployment. Some of the reasons given for increasing unemployment are: over dependence on oil; and negligence of other critical sectors of the economy like agriculture, manufacturing and mining. Presently, Nigeria is experiencing rising unemployment rate of 23.9 percent, population of unemployed youth of 20.3 million and about 4.5 million new entrants enter the labour market annually. About 2.2 million primary school leavers are withdrawing from secondary school; one million secondary school leavers are withdrawing from tertiary education; and roughly 600,000 students graduate annually without any hope of finding job (NBS, 2012 as cited by Philip, Samson and Ogwu, 2013). This situation is a serious challenge to the economy of Nigeria. According to the report of World Bank Survey in 2011, 40 percent of those who join militancy movement indicated that they are motivated by unemployment; while 50 percent of those involved in criminal activities are also stimulated by unemployment.

With large population and inability of government to provide job, attention has been focused on informal sectors as a probable panacea to curb unemployment since it constitutes a significant part of the Nigerian economy, and it employs large number of non-agricultural workers in many developing countries (Jessica, 2009). Informal sector is any income-generating activities that operate outside the regulatory framework of the state (Castells and Portes, 1989; De Soto, 1989; Meagher, 2013). According to Fields (2006), it is has been described as informal or unregistered sectors comprising informal employment (work without secure contracts, worker benefit, or social protection) of two kinds: self-employment in informal enterprises (small or unregistered enterprises) and paid employment in informal jobs (casual labour, or outworkers or unregistered, or temporary, or unprotected workers).

Various policies have been implemented by the Nigerian government to encourage informal sectors as a way of reducing unemployment in Nigeria. However, outcomes have varied across the years with recorded cases of little progress. For instance, the Central Bank of Nigeria (CBN) (1998) observed that the Structural Adjustment Programme (SAP) of 1986 induced the unprecedented growth of the informal sectors activities. The Structural Adjustment Programme had serious impact on unemployment rate by reducing it from 7.1 percent in 1987 to as low as 1.8 per cent in 1995. After which it rose to 3.4 per cent in 1996, and hovered between 4.3 and 4.7 percent between 1996 and 2000 (Douglason and Gibosi, 2006). It is impressive to note here that, in 2003 Nigeria's unemployment rate declined substantially to 2.3 percent (National Bureau of Statistic (NBS), 2004). This decline was attributed to the encouragement of informal sectors by the Nigerian government. Similarly, in the third quarter of 2014, it was reported that a total of 349,343 jobs were created across all sectors of the Nigerian economy. Of these, 5,735 or $1.64 \%$ was recorded in the public sector, 145,464 or $41.6 \%$ was in the formal sector and 198,144 or $56.72 \%$ in the informal sectors (NBS, 2015). 
Notwithstanding the success of informal sectors above, there is controversy on the relationship between informal sectors and unemployment. This disagreement hinged heavily on the method of measuring informal sectors. Some studies faulted the direct method (micro analysis) of measuring informal sector based on its method of using surveys data. The argument was that, this measure may not be reliable because, informal agents are not necessarily motivated to cooperate when reporting their true information at the time of data collection. Aside from this, the method focused on sampling of informal employers and employees within an industry or geographic location, thus any information obtained is likely to be untrue and the results obtained could be biased (Brambila-Macia, 2010).

In recent studies, attention on measuring informal sectors has been shifted to a macro method. This method entails capturing and analyzing the underground economy by using the currency in circulation ratio that include several measures of money. Some of these studies include the work of Kufman, Johnson and ZoidoLobaton (1998); Schneider and Enste (2000); Giles and Tedds (2002); Bajada and Schneider (2005); Dell'Anno and Solomon (2007); Brambila-Macia (2010); Dobre, Alexandru and Ghinararu (2010). Most of these studies focused mainly on $1^{\text {st }}$ and $2^{\text {nd }}$ world economy with little attention on the $3^{\text {rd }}$ world economy, of which Nigeria is included. Few studies in Nigeria that considered the macro measure of the informal sectors and its influence on unemployment include the work of Fasanya and Onakoya (2012) who proxied informal sectors with output of informal sectors per worker; and Ogbuabor and Malaolu (2013) that used currency in circulation (M1) as a indicator for informal sectors. However, the study of Ogbuabor and Malaolu (2013) failed to consider important proxies of Informal sector such as the discrepancy between aggregate expenditure and aggregate income, and discrepancy between labour force and formal employment. It is on this premise that this study sets out to analyse the impact of informal sectors on unemployment in Nigeria by considering the various measures of informal sectors.

\section{Literature Review}

Results of studies on informal sector and unemployment have shown that, older firms have greater ability to employ more labour, but an increase in wages and cost of capital in the long run tend to discourage labour employment (see Folawewo, 2006). The role of informal sectors on the level of unemployment and poverty level cannot be underrated in the world economy. According to Chukuezi (2010), informal sector is the second largest employer of labour after agriculture in the world including Nigeria. The finding also indicated that the informal sectors is a refuge ground for retrenched workers from the formal sector, unemployed youth and fresh university graduates in the third world countries especially Nigeria.

In the study of Emmanuella (2010), it was found that people of low-income in Nigerian cities rely mainly on the informal sectors for survival because the sector provides many opportunities to support their meager income; the study further pointed out that the sector develops and changes over time and it interacts with and affects the environment leading to environmental degradation resulting from the informal sectors activities which have been neglected on a large scale.

Also, while examining the level of employment generation in the informal sectors in Nigeria, Fasanya and Onakoya (2012) using an error correction model and adopting Mankiew, Romer and Weil (1992) model discovered that informal sectors have positive impact on employment generation than the formal sector. It was noted that a unit increase in informal sector, brings about 569 percent decrease in unemployment rate compare to the formal sector output which can only cut unemployment down by 75 percent. The work of Fasanya and Onakoya (2012) authenticates the finding of Akerele (1997) and Dessy and Pallage, (2003) that informal sectors activities have substantially absorb the large pool of labour force than the formal sector, hence, reduces the rate of unemployment.

In the descriptive approach to employment and income opportunities available in the informal sectors especially with the decline of employment opportunities in the formal sector, Duru (2012) observed that the 200 informal sectors activities that were surveyed were likely to create or generate 690 jobs. His study showed that all participants in the informal sectors activities have had one form of formal education or the other. This shows a tremendous improvement from earlier studies that indicated low level of educational attainment for participants in the informal sectors. In another descriptive study on how informal vocational apprentice cater for their training in Lagos State, where data were collected from 480 apprentices, 40 masters, 20 journeymen, and 120 members of various communities through a structured questionnaire.

Furthermore, the findings of Akinwale (2012) showed that 64.8 percent of the respondents reported parental sponsorship of vocations in the informal sectors, 14.2 percent of the respondents were self-sponsored, and the remainders (18.5 percent and 2.5 percent) were reportedly sponsored by their relatives and masters. Awareness of opportunities for self employment in the informal sectors was demonstrated by 71 percent of the respondents. However, the study reported that planning for self employment was significantly influenced by several factors including gender, age, mothers' occupation, career plan, and satisfaction within the informal sectors. The informal sector is therefore perceived to be vital for survival of youth in Lagos State, Nigeria and 
can support poverty reduction and entrepreneurial development. A study that focused on the challenges of improving informal sectors activities' conditions in Lagos Island, Nigeria by Farinmade (2012) adopted a survey technique using stratified random sampling. The study showed that there exists a relationship between employment in the informal sectors and formal sector unemployment, illiteracy, environmental degradation and the rampant violation of planning regulations. The study therefore recommended the formulation of policies and programmes that will enhance the effectiveness of both the informal sectors and planning administration, provision of infrastructure that promote informal sectors activities.

In addition to the above, Philip, Samson and Ogwu (2013) attempted to explore the role

of the informal sectors as a strategy for reducing unemployment in Nigeria, especially in Kogi state. The study employed the survey research design using data collected from both secondary and primary sources. The Chisquare tool of analysis was used and the result indicated that the informal sectors in Nigeria are not a threat to the socio-economic fortune of the state. The study suggested that government should encourage informal sectors through funding, capacity building, infrastructural facilities etc.

After observing the consistent retirement of workers from the formal sector in Nigeria in recent time, Ezi (2014) found that the bulk of retirees spent their pension on basic service which makes it insufficient and force about 80 percent of retiree to return back to the informal sectors. The study also showed that the informal sectors play a great role in determining income security in old age.

Moving outside Nigeria, study on the employment and informal sectors based on a field survey in low-income neighborhoods of Istanbul conducted by Ozar (1998) showed that 65.8 percent of the informally employed has at most a primary school education. This confirms Tansel (1998) emphasis on the level of education as a promoter of informal sector. The study also states that 80.5 percent of the working population is under informal employment. Evidence however also indicates that not all informal workers are all lowincome earning people employed in the informal sectors.

Another report from ILO (2002a and 2002b) noted that, in South African statistics, the number of employees in the informal sectors have been growing significantly. The National Household Survey showed that from 1997 to 2005 the number of employees in the informal sectors increased at about 1.1 million, making up to roughly 1.9 million employed in the informal sectors. It was also found that the activities that led to this increase include street vending, shoe repair, hairdressing, transport, and manufacturing and others. However, the majority of the informal sectors workers operators are concentrated in trade activities, followed by construction, manufacturing and services

Similarly, another study's reports from Alice Town in the Eastern Cape Province of South Africa suggested that small business which is a subset of the informal sectors can break poverty cycle, promote faster rate of economic growth and development if effective measures are taken to support it (Tshuma and Jari, 2013). This then implies that, for informal sector to reduce unemployment and increase output, other necessities should be put into consideration. In the case of the nature of labour market informalization and its links with poverty and household survival, Beneria and Floro (2003) using questionnaire on a sample survey obtained from the poor urban household engaging in home-based work, collected information from four hundred and eighty-four women and men respondents in two hundred and forty-two couples household sub-sample in Bolivia and Ecuador. He attempted to capture different levels of economic security faced by men and women in urban poor community by measuring the degree of informality, access to or lack of social protection, earnings and income variability. The results suggested that 95 percent and 79 percent of the sample living in urban low-income area of Bolivia and Ecuador respectively have main jobs that are moderate or severely informal. Women in the urban household sample tend to have relatively more precarious jobs than men in both countries, implying greater vulnerability. The study also showed that with the decline in economic and job security, workers tend to engage in more than one job. Nearly a sixth of the total respondent in the Bolivia sample hold more than one job which shows a coping mechanism that serves as a buttress against job and income security. But in the case of Ecuador, the proportion of those with more than one job is less for both men and women. The study further indicated that about 18-20 percent of urban workers in the low-income communities have solely formal jobs and are predominantly men, the majority (about 77 percent and 60 percent of Bolivia and Ecuador sample respondents) are engaged in both formal as well as informal jobs because most of their formal jobs are either on a part time basis or inadequate in meeting their subsistence need. Again, this further shows the roles of informal sector in reducing unemployment in the economy.

\section{Theoretical Framework And Model Specification}

The theoretical framework underpinning this study is rooted in the augmented Solow growth model of Mankiew, Romer and Weil (1992). Prior to the this model, Solow (1956), stipulated that economic growth is a result of the accumulation of physical capital and also the expansion of the labour force in conjunction with an exogenous factor, the technological progress that makes physical capital and the labour market more productive. Mankiew etal. (1992) further extended the Solow model to include human capital. In 
line with this, the link between unemployment and the various indirect measures of informal sectors can be examined using the Mankiew, Romer and Weil (1992) as specified by Onakoya and Fasanya (2012).

$$
\begin{aligned}
& \ln U N E M P_{t}=\alpha_{0}+\alpha_{1} A I_{-} A E_{t}+\alpha_{2} \ln L F_{-} F E_{t}+\alpha_{3} I F S O_{t}+ \\
& \alpha_{4} M 1_{t}+\alpha_{5} \ln H C_{t}+\varepsilon_{t}
\end{aligned}
$$

Where: $\mathrm{UNEMP}_{\mathrm{t}}=$ Unemployment rate; $\mathrm{AE}_{-} \mathrm{AI}_{\mathrm{t}}=$ Differences between aggregate expenditure and aggregate income (as a proxy for informal sectors) $\mathrm{LF}_{-} \mathrm{FE}_{\mathrm{t}}=$ Differences between labour force and formal employment (as a proxy for informal employment); $\mathrm{IFSO}_{\mathrm{t}}=$ Formal sector output per worker (as a proxy for informal sectors); $\mathrm{M}_{\mathrm{t}}=$ Currency in ratio (as a proxy for informal sectors); $\mathrm{HC}_{\mathrm{t}}=$ Ratio of Education spending to total population (as a proxy for Human capital).

\section{Data, Sources Of Data And Methods Of Estimation}

Annual data on unemployment rate, narrow money supply (M1), broad money supply

(M2), government spending on education, Gross Domestic Product by income at purchasers' prices and Gross Domestic Product by expenditure at current purchasers' price were obtained from the Central Bank of Nigeria (CBN, 2013) Statistical Bulletin. Data on Labour force, labour participation rate and population were obtained from World Development Indicators (WDI). Vector Error Correction Model (VECM) was used to analyze the effects of informal sectors on unemployment in Nigeria using the various indirect measures of informal sectors. We examine the mean, median, maximum, minimum value Kurtosis, skewness and Jaque-Bera statistics of each variable to ensure the normality of our variables so as to circumvent the problem of model misspecification. The results show that the variables used have low standard deviation with the result of Jaque-Bera statistics showing normality of our variables. We also test for the stationarity of our data using both the Augmented Dickey-Fuller (ADF) and Phillips-Perron (PP) tests. Since all our variables are integrated of the same order I(1) except for the informal sectors output (IFO), we then dropped it to avoid unbiased VEC estimate. The results of ADF and PP are presented in Tables 1 and 2 in the appendix. The cointegration test was also carried out to test for the longrun association among the variables. The results indicate three co-integrating equation at 5\% significant level. These results are presented in Tables 4, 5 and 6 in the appendix. Our lag length was selected using SBIC, and then tested for the stability of the model using the Inverse Root of Auto-Regressive (AR) Characteristics Polynomial. The results show that there is stability in the estimated VEC model because the modulus are less than one and also all the root dots lie inside the unit circle which symbolize stability of our model. Following this, we apply the Vector Error Correction Method.

\section{Discussion Of Results, Conclusions And Recommendations}

Our results showed negative relationship between informal sector and unemployment in the long run in Nigeria. This finding further supports the work of Arosanyin, Olowosulu and Oyeyemi, 2011; Duru, 2012; and Fasanyan and Onakoya, 2012 where it was noted that informal sectors impacted unemployment rate negatively. This is reasonable since the unemployed will always strive to survive in the face of unemployment. Specifically, the result of the discrepancy between labour force and formal employment in Nigeria (lnLF_FE) as a measure for informal sectors show that it has serious impact on unemployment reduction. It was discovered that $1 \%$ increase informal sectors in Nigeria causes a reduction of unemployment by $24.7 \%$ in the long run. This result corroborates the $21.7 \%$ reported by Arosanyin, Olowosulu and Oyeyemi, (2011) in their study. The result also authenticates the work of Ogunrinola (2010) who reported that the informal sectors is a high employer of young school leavers who just joined the labour force and reported that the informal sectors employed a large share of labour force in developing countries. It was also noted that $1 \%$ increase in the discrepancy between aggregate expenditure and aggregate income (AE_AI) as a measure of informal sectors in Nigeria indicated a reduction of unemployment by $0.002 \%$ in the long run. This result is in line with the finding of Onyemachi (2013) who considered informal sectors from the point of income approach by laying claim that the informal sectors reduced unemployment and provided income for the teeming poor. The coefficient of currency ratio (M1) as a measure for informal sectors is however very low compared to that of lnLF_FE in the sense that it reduced unemployment in the long run by $2.9 \%$. This however, might be as a result of the rural dwellers in Nigeria who have limited access to banking service and still resorted to barter system of transaction in most of their services. This supports the claim by Thomas $(1986,1999)$ and Feige (1986) who argue that cash in circulation only give a rough indication of informality because it is not all informal transactions that are performed in cash. Lastly, in line with the study of Fasanya and Onakoya (2012), who found that human capital positively affect unemployment in Nigeria, this study also supported the evidence that human capital had a positive effect on unemployment in the long-run in Nigeria where a $1 \%$ increase in human capital in Nigeria caused increased unemployment of $0.29 \%$. This could be as a result of the sustainable graduate output with skills mismatch and without corresponding increase in employment and sustainable support base for enterprising graduate in Nigeria. 
Since the probability value for the VECM estimate is not given, in order to test for significance of the variable both in the long run and short run, it is therefore important to estimate an Ordinary Least Square Regression model (see Mukhtar and Rasheed, 2010). Given this, the results in Table 7 show the p- value for the long-run error correction model estimate in Table 5 and Table 6. It also shows the short run p-value of Unemployment and its dependent lags variables. The unemployment rate (LNUNEMP) indicated a probability value of 0.0002 which is significant at $1 \%$ significance level. This signifies that there is a long run significant effect of all the independent variable on unemployment in Nigeria. The coefficient of unemployment (LNUNEMP) which is -0.04768 also suggests that there is a fast speed of adjustment of roughly $48 \%$ from the shot-run disequilibrium to the long run equilibrium. This implies that the model will achieve a long-run equilibrium or convergence when there is an error in the model due to economic shock. This also re-affirms the existence of cointegration among the variables.

To test for the short run relationship between informal sector and unemployment in Nigeria, we subject the 3 lag coefficient of each of the independent variable to Wald statistics in order to determine the significant of their joint effects on unemployment in Nigeria in the short run. This is also shown in Table 8. In the Table, since the null hypothesis of the discrepancy of aggregate expenditure and aggregate income as a measure for informal sectors (AE_AI) is rejected at 5\%, it indicates that all the three lag variables jointly impact unemployment rate in the short run. Of the three lagged period of the discrepancy between aggregate expenditure and aggregate income, the third period has the better short term significant effect at $10 \%$, level of significance, where the informal sectors significantly reduced unemployment by $-0.0099 \%$. On each lagged period, the first and second periods are insignificant.

Similarly, the discrepancy of labour force and formal employment as a measure of informal sectors (LNLF_FE) rejects the null hypothesis that the 3 lag period is equal to zero at 5\% level of significant. This suggests that all the lag variable of the discrepancy of labour force and formal employment as a measure of informal sectors in Nigeria jointly impact unemployment rate in the short run. In studying each of the lagged period, we found that informal sectors positively affect unemployment significantly at the second period (year). A $1 \%$ increase in the informal sectors causes $21.7 \%$ increase in unemployment in the second period, even though the long run suggests a negative relationship. This may be informed by the reason that young graduates who join the labour force crave for formal employment in the short run due to their high reservation wage demand, but filter into the informal activities in the long run when the reality of limited number of formal employment began to manifest.

On the other hand, the three lag period of currency ratio (M1) as a proxy for informal sectors follows the apriori expectation. It shows that all the three lagged period have significant effect on unemployment and reduces unemployment in the short run as indicated by the negative sign. The strongest effect is felt in the first period than the second and third lagged period where a $1 \%$ increase in the informal sectors (as measure by currency ratio) reduces unemployment by $-9.97 \%$ at $1 \%$ level of significance. Similarly, the Wald statistic reject the null hypothesis that the combination of each period is equal to zero at 5\% and suggests that all the three lag period of currency ratio (M1) jointly impact unemployment rate in Nigeria.

Human capital ((LNHC) in Nigeria does not significantly affect unemployment in the short run even though it follows apriori expectation as the Wald statistic accepts the null hypothesis that the three lag period of human capital is equal to zero. The $\mathrm{R}^{2}$ in the study showed that the equation has a good fit because $81 \%$ of the variation in unemployment is explained by this model. The adjusted $\mathrm{R}^{2}$ which was made to purge the influence of the number of included explanatory variable also showed a good fit of $56 \%$.

The study recommends that policies that could promote informal sectors such as patronage of local goods, tax holiday for new entrants, easy access to finance and infrastructure development should be encouraged. Human capital development such as investment in technical education and revision of school curriculum to inculcate development of the youths before they attain the age of entering the labour force should also be promoted.

\section{References}

[1] Akerele W.O. (1997). "The effect of Economic adjustment on employment in the urban informal sectors of Ibadan City. NISER monograph series No. 14 , pp. 22-25

[2] Akinwale, A. A. (2012). The informal sector as a catalyst for employment generation in Lagos state, Nigeria. African and Asian Studies, Vol. 11, No.3, pp. 315-344.

[3] Arosanyin, G.T., Oluwosulu, A.T., and Oyeyemi, G.M. (2011). "Employment generation and earnings in the informal transport sector in Nigeria". International Business and management. Vol. 2, No.2, pp. 139-148.

[4] Bajada, C., and Schneider, F. (2005). "The Shadow Economies of the Asia-Pacific"' Pacific Economic Review, 10(3), pp.379-401

[5] Beneria, L. and Floro, M. (2003). "Distribution, Gender, and Labour Market Informalization: A conceptual framework with a focus on home workers". RETHINKING,

[6] Brambila-Macia, J. (2010). "Modeling the informal Economy in Mexico. A Structural Equation Approach". Guido Cazzavillan. The Journal of Developing Areas, vol. 44, No 1, pp 345-365 
[7] Castells, M. and Portes, A. (1989). "World underneath: The origins, dynamics, and effects of the informal economy", in A. Portes, M. Castells and L.A. Benton (eds.), The informal Economy: Studies in Advanced and less Developed countries, London: The John's Hopkins University Press

[8] CBN, (1998), Structural Bulletin - Central Bank of Nigeria. (2013). Statistical Bulletin - Central Bank of Nigeria

[9] Chukuezi, C.O. (2010). "Urban Informal sectors and unemployment in third world cities: The situation in Nigeria". Asian Social Science, vol.6, No.8.

[10] Dell'Anno, R., and Solomon, O.H. (2007). "Shadow Economy and Unemployment rate in USA: is there a structural relationship? An empirical analysis". Applied Economics, pp. 1-19.

[11] Dessy, S. and Pallage, S. (2003). "Taxes, Inequality and the size of the informal sectors". Journal of Development Economics. Vol. 70, pp. $225-233$

[12] De Soto, H. (1989). "The other path: The Economic Answer to Terrorism. New York: HarperCollins.

[13] Dobre, I; Alexandru, A.A. and Ghinararu, C.C. (2010). "The relationship between shadow economy and unemployment rate: A SVAR approach". Proceedings of the 5th WSEAS International Conference on Economy and Management Transformation (Vol. 1). ISSN: $1792-5983$

[14] Douglason, G.U. and Gibosi, A. (2006). "The Dynamics of Productivity and Unemployment Nexus": Implications for Employment Generation in Nigeria NES 2006: Annual Conference, Ibadan, Nigeria.

[15] Duru, M. (2000). "Human Capital formation: A case study of the apprenticeship system in Nigeria's informal sectors". A Ph.D thesis Submitted to the department of Economics, Ahmadu Bello University, Zaria.

[16] Duru, M. (2012). "Nigeria's informal sectors: Opportunities for self employment and income generation". Economics and fiancé review vol. 1(11) pp35-41. Retrieved from www.businessjournalz.org/efr

[17] Emmanuella C.O. (2010). "Study on The Informal Sector and the Environment in Nigeria Towns: What we know and what we still need to know": Research journal of environment and health science, Vol. 3, No. 1.

[18] Ezi, B. (2014). "Retired but not Tired": Linking Retirement and Informality of Labour". Asian Journal of humanities and social sciences, vol. 2 - issue 1.

[19] Folawewo, A.O. (2006). "Determinants of Informal sectors labour demand: An application of alternative methodological approaches to South Western States of Nigeria". Applied Econometrics and international development (AEID Vol. 6-2.

[20] Farinmade A. (2012). "Challenges of Improving Informal sectors Activities Conditions in Lagos Island, Nigeria": British Journal of Arts and social science Vol. 6 No. 2.

[21] Fasanya I.O. and Onakoya, B.O. (2012). "Informal sectors and Employment Generation in Nigeria: An Error Correction Model". Research on humanities and social sciences, ISSN 2222 - 1719 paper vol. 2, No. 7.

[22] Feige, E. (1986). "A Re-examination of the underground economy in the United States": A comment on Tanzi, IMF- Staff papers 33, No. 4, pp. $768-81$.

[23] Fields, G.S. (2006). "Modelling labour market policy in Developing countries: A selective review of the literature and needs for the future: mimeo, Cornell University.

[24] Giles, D., and Tedds, L. (2002). “Taxes and The Canadian Underground Economy”. Canadian Tax Foundation Toronto, Paper No. 106 , Canada.

[25] ILO (2002a). "Decent work and the informal economy". Report VI. Presented by the Director General at the 90th session of the International Labour conference, Geneva, Switzerland. . (2002b). "Women and Men in the Informal Economy: A statistical picture". International Labour Office, Geneva.

[26] Jessica, L. (2009). "Formal and Informal Microenterprises: Enterprise surveys, enterprise note series". The World Bank, International Finance Corporation.

[27] Kaufman, D., Johnson, S. and Zoido-Lobaton, P. (1998).. "Regulatory Discretion and the Unofficial Economy", American Economic Review.

[28] Mankiw, N.G., Romer, D., and Weil, N.W. (1992). "A Conribution to the Empirics of Economic growth". The Quarterly Journal of Economics, Vol. 107, No. 2, pp. 407-437. Oxford University Press.

[29] Meagher, K. (2013). "Unlocking the informal economy: A Literature review on linkages between formal and informal economies in developing countries". WIEGO working paper No. 27

[30] Mukhtar, T., and Rasheed, S. (2010). "Testing Long-run Relationship between Exports and Imports: Evidence from Pakistan". Journal of Economic cooperation and development, 31, 1(2010), 41-58.

[31] National Bureau of Statistics (2012). Labour force survey, March, 2012. Abuja: National Bureau of statistics.

[32] National Bureau of Statistics (2004). Nigeria Statistical Fact Sheets on Economic and Social Development, FOS, Nigeria.

[33] National Bureau of Statistics (2015). "3rd Quarter Job Creation Survey Report". FOS, Nigeria.

[34] Ogbuabor, J.E. and Malaolu, V.A. (2013). "Size and causes of the informal sectors of the Nigerian Economy: Evidence from error correction MIMIC model". Journal of Economics and Sustainable Development, vol. 4, No. 1.

[35] Ogunrinola, I. O. (2010). "Informal Self-Employment and Poverty Alleviation: Empirical Evidence from Motorcycle Taxi Riders in Nigeria": International Journal of Economics and Finance.

[36] Onyemaechi, J.O. (2013). "Role of the informal sectors in development of the Nigerian Economy: Output and employment approach". Journal of Economics and Development studies, 1(1), June, pp. 60-74.

[37] Ozar, S. (1998). "The Employment Aspects of the Informal sectors: A Field Survey in Low-Income Neighbourhoods of Istanbul", in T. Bulutay (ed.), Informal sectors II, Ankara: State Institute of Statistics.

[38] Philip, A.A., Samson, A.J. and Ogwu, H.P. (2013). "Strategy for reducing unemployment in Nigeria: The role of informal sectors". International Journal of capacity building in education and management, vol.2, No.1.

[39] Schneider, F. and Enste, D.H. (2000). "Shadow Economies: Size, Causes, and Consequences", Journal of Economic Literature, 38/1, pp. 77-114.

[40] Solow, R.M., (1956). “A Contribution to the Theory of Economic Growth,'. Quarterly Journal of Economics, LXX, 65-94.

[41] Tansel, A. (1998). "Formal versus informal sectors choice of wage earners and their wages in Turkey", in T. Bulutey (ed), informal sectors I, Ankara state institute of statistics.

[42] Thomas, J. (1986). "The Underground Economy in the United States: Comments on Tanzi”. IMF staff papers, vol. 33, No. 4, pp. $782-788$. 456, pp. 381-389.

[43] Tshuma, M. C. \& Jari, B. (2013). "Informal sectors as a source of Household Income: The case of Alice Town in the Eastern Cape Province of South Africa": Journal of African studies and development vol. 5, No.8. 
Appendix

Table 1: Result of the Augmented Dickey Fuller (ADF) Unit Roots Test on Variables

\begin{tabular}{|l|l|l|l|l|}
\hline \multirow{2}{*}{ VARIABLES } & AUGMENTED DICKEY FULLER & \multicolumn{2}{l|}{} \\
\cline { 2 - 5 } & Level & $\mathbf{1}^{\text {st }}$ Difference & $\mathbf{2}^{\text {nd }}$ Difference & Remark \\
\hline $\ln$ UNEMP & -0.334834 & $-5.090414^{*}$ & - & $\mathrm{I}(1)$ \\
\hline AE_AI & -2.066464 & $-2.865781^{* * *}$ & - & $\mathrm{I}(1)$ \\
\hline $\operatorname{lnLF}$ FE & -1.515869 & -4.788869 & - & $\mathrm{I}(1)$ \\
\hline IFSO & $-7.448755^{*}$ & - & - & $\mathrm{I}(0)$ \\
\hline M1 & -1.140191 & $-5.297798^{*}$ & - & $\mathrm{I}(1)$ \\
\hline $\operatorname{lnHC}$ & -1.469706 & $-5.046234^{*}$ & - & $\mathrm{I}(1)$ \\
\hline
\end{tabular}

Source: Author's Computation, 2015

NOTE: One, two and three asterisk denotes rejection of the null hypothesis at $1 \%, 5 \%$ and $10 \%$ respectively based on critical value. For the augmented Dickey -Fuller (ADF) test, the automatic maximum lag length based on Schwarz information criterion is applied.

Table 2: Result of the Phillips - Perron Unit Roots Test On Variables

\begin{tabular}{|l|l|l|l|l|}
\hline \multirow{2}{*}{ VARIABLES } & \multicolumn{4}{l|}{ PHILLIPS - PERRON TEST } \\
\cline { 2 - 5 } & Level & $\mathbf{1}^{\text {st }}$ Difference & $\mathbf{2}^{\text {nd }}$ Difference & Remark \\
\hline lnUNEMP & -0.614454 & $-5.166315^{*}$ & - & $\mathrm{I}(1)$ \\
\hline AE_AI & -1.438764 & $-2.816716^{* * *}$ & - & $\mathrm{I}(1)$ \\
\hline $\operatorname{lnLF}$ FE & -1.473454 & $-4.913587^{*}$ & - & $\mathrm{I}(1)$ \\
\hline IFSO & -1.702626 & -1.764008 & -2.089284 & - \\
\hline M1 & -1.344852 & $-5.295511^{*}$ & - & $\mathrm{I}(1)$ \\
\hline $\operatorname{lnHC}$ & -0.809739 & -8.830102 & - & $\mathrm{I}(1)$ \\
\hline
\end{tabular}

Source: Author's Computation, 2015

NOTE: One, two and three asterisk denotes rejection of the null hypothesis at $1 \%, 5 \%$ and $10 \%$ respectively based on critical value. For the Philips-Perron (PP) test, the automatic maximum lag length based on Newey-West Bandwidth is applied.

Table 3: Co-Integrating results (with a linear deterministic trend) where $r$ is the number of cointegrating vectors [Lag interval (1 to 3)]

\begin{tabular}{|c|c|c|c|c|c|c|c|}
\hline \multicolumn{4}{|c|}{ Trace Test } & \multicolumn{4}{|c|}{ Max-Eigen Test } \\
\hline Null & Alternative & Statistic & $\begin{array}{l}\text { Critical } \\
\text { Value }(5 \%)\end{array}$ & Null & Alternative & Statistic & $\begin{array}{l}\text { Critical } \\
\text { Value }(5 \%)\end{array}$ \\
\hline $\mathrm{r}=0^{*}$ & $r=1$ & 131.3052 & 69.81889 & $\mathrm{r}=0^{*}$ & $r=1$ & 56.08900 & 33.87687 \\
\hline $\mathrm{r} \leq 2^{*}$ & $r=3$ & 36.07315 & 29.79707 & $r \leq 2 *$ & $r=3$ & 23.04145 & 21.13162 \\
\hline $\mathrm{r} \leq 3$ & $r=4$ & 13.03170 & 15.49471 & $r \leq 3$ & $r=4$ & 8.661792 & 14.26460 \\
\hline $\mathrm{r} \leq 4^{*}$ & $r=5$ & 4.369911 & 3.841466 & $r \leq 4^{*}$ & $r=5$ & 4.369911 & 3.841466 \\
\hline
\end{tabular}

Source: Author's Computation 2015 by E-views7

Table 4: Estimates of co-integrating vector (Dynamic Long-Run Relationship)

\begin{tabular}{|l|l|l|l|l|}
\hline LnUNEMP & AE_AI & LnLF_FE & M1 & lnHC \\
\hline 1.000000 & 0.001733 & 24.69943 & 2.927540 & -0.571619 \\
\hline & $(0.00608)$ & $(9.47687)$ & $(1.88334)$ & $(0.14934)$ \\
\hline
\end{tabular}

Note: standard errors are in parentheses

Table 5: Error correction model

\begin{tabular}{|l|l|l|l|l|}
\hline LnUNEMP & AE_AI & LnLF_FE & M1 & lnHC \\
\hline-0.476805 & 0.780045 & -0.003325 & -0.002794 & -0.244450 \\
\hline$(0.09078)$ & $(4.05285)$ & $(0.00396)$ & $(0.01472)$ & $(0.30458)$ \\
\hline
\end{tabular}

Note: standard errors are in parentheses

Table 6: Estimates of short run model

\begin{tabular}{|l|l|l|l|l|l|}
\hline & D(LNUNEMP) & D(AE_AI) & D(LNLF_FE) & D(M1) & D(LNHC) \\
\hline D(LNUNEMP(-1)) & -0.376963 & 11.57358 & -0.000638 & 0.028200 & 0.179560 \\
& 0.17830 & $(7.95980)$ & $(0.00778)$ & $(0.02891)$ & $(0.59820)$ \\
& {$[-2.11424]$} & {$[1.45400]$} & {$[0.08209]$} & {$[0.97543]$} & {$[0.30017]$} \\
\hline D(LNUNEMP(-2)) & 0.210628 & -1.358476 & 0.003928 & -0.000635 & -0.226799 \\
& $(0.16755)$ & $(7.48009)$ & $(0.00731)$ & $(0.02717)$ & $(0.56215)$ \\
& {$[1.25709]$} & {$[-1.18161]$} & {$[0.53743]$} & {$[-0.02338]$} & {$[-0.40345]$} \\
\hline D(LNUNEMP(-3)) & 0.441582 & -2705023 & 0.006577 & -0.013317 & 0.382907 \\
& $(0.15556)$ & $(6.94484)$ & $(0.00679)$ & $(0.02522)$ & $(0.52192)$ \\
\hline
\end{tabular}


Informal Sectors and Unemployment in Nigeria: A Vector Error Correction Model (VECM) Approach

\begin{tabular}{|c|c|c|c|c|c|}
\hline & {$[2.83861]$} & {$[-0.38950]$} & {$[0.96930]$} & {$[-0.52793]$} & {$[0.73365]$} \\
\hline D(AE_AI(-1)) & $\begin{array}{l}0.010962 \\
(0.00694) \\
{[1.57900]}\end{array}$ & $\begin{array}{l}0.348500 \\
(0.30992) \\
{[1.12447]}\end{array}$ & $\begin{array}{l}5.67 \mathrm{E}-05 \\
(0.00030) \\
{[0.18740]}\end{array}$ & $\begin{array}{l}-0.002163 \\
(0.00113) \\
{[-1.92117]}\end{array}$ & $\begin{array}{l}-0.031371 \\
(0.02329) \\
{[-1.34690]}\end{array}$ \\
\hline D(AE_AI(-2)) & $\begin{array}{l}-0.007951 \\
(0.00796) \\
{[-0.99909]}\end{array}$ & $\begin{array}{l}0.235171 \\
(0.35529) \\
{[0.66192]}\end{array}$ & $\begin{array}{l}-0.000114 \\
(0.00035) \\
{[-0.32731]}\end{array}$ & $\begin{array}{l}0.002157 \\
(0.00129) \\
{[1.67148]}\end{array}$ & $\begin{array}{l}0.024572 \\
(0.02670) \\
{[0.92027]}\end{array}$ \\
\hline D(AE_AI(-3)) & $\begin{array}{l}-0.009858 \\
(0.00527) \\
{[-1.87129]}\end{array}$ & $\begin{array}{l}-0.203362 \\
(0.23519) \\
{[-0.86466]}\end{array}$ & $\begin{array}{l}1.72 \mathrm{E}-05 \\
(0.00023) \\
{[0.07499]}\end{array}$ & $\begin{array}{l}-0.001245 \\
(0.00085) \\
{[-1.45779]}\end{array}$ & $\begin{array}{l}-0.011120 \\
(0.01768) \\
{[-0.62910]}\end{array}$ \\
\hline D(LNLF_FE(-1)) & $\begin{array}{l}3.684845 \\
(6.88029) \\
{[0.53557]} \\
\end{array}$ & $\begin{array}{l}-169.1860 \\
(307.160) \\
{[-0.55081]}\end{array}$ & $\begin{array}{l}0.258717 \\
(0.30012) \\
{[0.86205]} \\
\end{array}$ & $\begin{array}{l}1.732939 \\
(1.11561) \\
{[1.55335} \\
\end{array}$ & $\begin{array}{l}5.636840 \\
(23.0838) \\
{[0.24419]}\end{array}$ \\
\hline D(LNLF_FE(-2)) & $\begin{array}{l}21.73669 \\
(7.82284) \\
{[2.77862]}\end{array}$ & $\begin{array}{l}-153.2616 \\
(349.238) \\
{[-0.43885}\end{array}$ & $\begin{array}{l}0.118021 \\
(0.34123) \\
{[0.34587]}\end{array}$ & $\begin{array}{l}-0.872088 \\
(1.26844) \\
{[-0.68753]}\end{array}$ & $\begin{array}{l}-14.18262 \\
(26.2461) \\
{[-0.54037]}\end{array}$ \\
\hline D(LNLF_FE(-3)) & $\begin{array}{l}12.99579 \\
(7.11364) \\
{[1.82688]}\end{array}$ & $\begin{array}{l}-162.1897 \\
(317.577) \\
{[-0.51071]}\end{array}$ & $\begin{array}{l}0.223220 \\
(0.31030) \\
{[0.71938]}\end{array}$ & $\begin{array}{l}-0.705944 \\
(1.15345) \\
{[-0.61203]}\end{array}$ & $\begin{array}{l}9.378862 \\
(23.8667) \\
{[0.39297]}\end{array}$ \\
\hline $\mathrm{D}(\mathrm{M} 1(-1))$ & $\begin{array}{l}-9.969509 \\
(2.00897) \\
{[-4.96249]}\end{array}$ & $\begin{array}{l}105.7437 \\
(89.6874) \\
{[1.17902]}\end{array}$ & $\begin{array}{l}0.026038 \\
(0.08763) \\
{[0.29713]}\end{array}$ & $\begin{array}{l}0.328670 \\
(0.32575) \\
{[1.00897]}\end{array}$ & $\begin{array}{l}7.035833 \\
(6.74023) \\
{[1.04386]}\end{array}$ \\
\hline $\mathrm{D}(\mathrm{M} 1(-2))$ & $\begin{array}{l}-6.450931 \\
(2.63434) \\
{[-2.44878]}\end{array}$ & $\begin{array}{l}114.4236 \\
(117.606) \\
{[0.97294]}\end{array}$ & $\begin{array}{l}-0.036217 \\
(0.11491) \\
{[-0.31518]}\end{array}$ & $\begin{array}{l}-0.173768 \\
(0.42715) \\
{[-0.40681]}\end{array}$ & $\begin{array}{l}-4.253146 \\
(8.83838) \\
{[-0.48121}\end{array}$ \\
\hline $\mathrm{D}(\mathrm{M} 1(-3))$ & $\begin{array}{l}-3.921124 \\
(1.83921) \\
{[-2.13196]}\end{array}$ & $\begin{array}{l}102.3763 \\
(82.1087) \\
{[1.24684]}\end{array}$ & $\begin{array}{l}0.037276 \\
(0.08023) \\
{[0.46463]}\end{array}$ & $\begin{array}{l}0.466061 \\
(0.29822) \\
{[1.56281]}\end{array}$ & $\begin{array}{l}-0.062371 \\
(6.17066) \\
{[-0.01011]}\end{array}$ \\
\hline $\mathrm{D}(\mathrm{LNHC}(-1))$ & $\begin{array}{l}-0.103141 \\
(0.10462) \\
{[-0.98590]}\end{array}$ & $\begin{array}{l}-5.142268 \\
(4.67040) \\
{[-1.10103]}\end{array}$ & $\begin{array}{l}-0.003786 \\
(0.00456) \\
{[-0.82959]}\end{array}$ & $\begin{array}{l}0.034069 \\
(0.01696) \\
{[2.00845]}\end{array}$ & $\begin{array}{l}-0.50071 \\
(0.35099) \\
{[-142473]}\end{array}$ \\
\hline $\mathrm{D}(\mathrm{LNHC}(-2))$ & $\begin{array}{l}0.158980 \\
(0.13522) \\
{[1.17571]}\end{array}$ & $\begin{array}{l}-0.203478 \\
(6.03671) \\
{[-0.03371]}\end{array}$ & $\begin{array}{l}0.000637 \\
(0.00590) \\
{[0.10804]}\end{array}$ & $\begin{array}{l}-0.019850 \\
(0.02193) \\
{[-0.90536]}\end{array}$ & $\begin{array}{l}-0969970 \\
(0.45367) \\
{[-2.13804]}\end{array}$ \\
\hline $\mathrm{D}(\mathrm{LNHC}(-3))$ & $\begin{array}{l}-0.069720 \\
(0.15493) \\
{[-0.45000]}\end{array}$ & $\begin{array}{l}4.972436 \\
(6.91674) \\
{[0.71890]}\end{array}$ & $\begin{array}{l}-0.005535 \\
(0.00676) \\
{[-0.81905]}\end{array}$ & $\begin{array}{l}0.031425 \\
(0.02512) \\
{[1.25092]}\end{array}$ & $\begin{array}{l}0.035704 \\
(0.51981) \\
{[0.06869]}\end{array}$ \\
\hline $\mathrm{C}$ & $\begin{array}{l}-0.097698 \\
(0.09398) \\
{[-1.03957]}\end{array}$ & $\begin{array}{l}2.368762 \\
(4.19555) \\
{[0.56459]}\end{array}$ & $\begin{array}{l}0.002163 \\
(0.00410) \\
{[0.52772]}\end{array}$ & $\begin{array}{l}-0.009899 \\
(0.01524) \\
{[-0.64958]}\end{array}$ & $\begin{array}{l}0.572021 \\
(0.31531) \\
{[1.81418]}\end{array}$ \\
\hline R-squared & 0.814408 & 0.778488 & 0.370264 & 0.671977 & 0.497121 \\
\hline Adj. R-squared & 0.566953 & 0.483139 & -0.469385 & 0.234612 & -0.173385 \\
\hline F- statistic & 3.291127 & 2.635822 & 0.440975 & 1.536422 & 0.741412 \\
\hline
\end{tabular}

Note: standard errors are in (), while t-statistics are in []

Table 7: VECM Estimation with p-value

\begin{tabular}{|c|c|c|c|c|c|}
\hline & Variable & Coefficient & Standard Error & t-Statistic & Probability \\
\hline $\mathrm{C}(1)$ & LNUNEMP & -0.476805 & 0.90783 & -5.252160 & 0.0002 \\
\hline $\mathrm{C}(2)$ & D(LNUNEMP(-1)) & -0.376963 & 0.178297 & -2.114237 & 0.0561 \\
\hline $\mathrm{C}(3)$ & D(LNUNEMP(-2)) & 0.210628 & 0.167552 & 1.257088 & 0.2326 \\
\hline $\mathrm{C}(4)$ & D(LNUNEMP(-3)) & 0.441582 & 0.155563 & 2.838614 & 0.0149 \\
\hline $\mathrm{C}(5)$ & $\mathrm{D}\left(\mathrm{AE} \_\mathrm{AI}(-1)\right)$ & 0.0100962 & 0.006942 & 1.578998 & 0.1403 \\
\hline $\mathrm{C}(6)$ & D(AE_AI(-2)) & -0.007951 & 0.007958 & -0.999090 & 0.3375 \\
\hline $\mathrm{C}(7)$ & $\mathrm{D}\left(\mathrm{AE} \_\mathrm{AI}(-3)\right)$ & -0.009858 & 0.005268 & -1.871291 & 0.0859 \\
\hline $\mathrm{C}(8)$ & D(LNLF_FE(-1)) & 3.684845 & 6.880294 & 0.535565 & 0.6020 \\
\hline $\mathrm{C}(9)$ & D(LNLF_FE(-2)) & 21.73669 & 7.822843 & 2.778617 & 0.0167 \\
\hline $\mathrm{C}(10)$ & D(LNLF_FE(-3)) & 12.99579 & 7.113638 & 1.826883 & 0.0927 \\
\hline $\mathrm{C}(11)$ & $\mathrm{D}(\mathrm{M} 1(-1))$ & -9.969509 & 2.008975 & -4.962487 & 0.0003 \\
\hline $\mathrm{C}(12)$ & $\mathrm{D}(\mathrm{M} 1(-2))$ & -6.450931 & 2.634345 & -2.448780 & 0.0307 \\
\hline $\mathrm{C}(13)$ & $\mathrm{D}(\mathrm{M} 1(-3))$ & -3.921124 & 1.839212 & -2.131958 & 0.0544 \\
\hline $\mathrm{C}(14)$ & $\mathrm{D}(\mathrm{LNHC}(-1))$ & -0.103141 & 0.104616 & -0.985899 & 0.3436 \\
\hline $\mathrm{C}(15)$ & D(LNHC(-2)) & 0.158980 & 0.135221 & 1.175709 & 0.2625 \\
\hline $\mathrm{C}(16)$ & $\mathrm{D}(\mathrm{LNHC}(-3))$ & -0.069720 & 0.154933 & -0.449997 & 0.6607 \\
\hline \multirow[t]{5}{*}{$\mathrm{C}(17)$} & Constant & -0.097698 & 0.093979 & -1.039570 & 0.3190 \\
\hline & $\mathrm{R}^{2}$ & 0.814408 & & & \\
\hline & Adj. $\mathrm{R}^{2}$ & 0.566953 & & & \\
\hline & F-Statistics & 3.291127 & & & \\
\hline & Prob. (F-Statistics) & 0.021200 & & & \\
\hline
\end{tabular}

Source: Author's Computation by E-views 7 
Table 8: Wald Test

\begin{tabular}{|l|l|l|l|l|}
\hline Variable & Test Statistics & Value & P-value & Null Hypothesis \\
\hline AE_AI & Chi-Square & 11.38851 & 0.0098 & $\mathrm{C}(5)=\mathrm{C}(6)=\mathrm{C}(7)=0$ \\
\hline LNLF_FE & Chi-Square & 11.86377 & 0.0079 & $\mathrm{C}(8)=\mathrm{C}(9)=\mathrm{C}(10)=0$ \\
\hline MI & Chi-Square & 24.71979 & 0.0000 & $\mathrm{C}(11)=\mathrm{C}(12)=\mathrm{C}(13)=0$ \\
\hline LNHC & Chi-Square & 4.578000 & 0.2054 & $\mathrm{C}(14)=\mathrm{C}(15)=\mathrm{C}(16)=0$ \\
\hline
\end{tabular}

Source: Author's Computation by E-views 7

Messiah, Abaka John. "Informal Sectors and Unemployment in Nigeria: A Vector Error Correction Model (VECM) Approach." IOSR Journal of Economics and Finance (IOSR-JEF) 8.4 (2017): 16-24. 